УДК 532.527

ББК 31.31

\title{
NEUTRALIZATION OF GAS EMISSIONS IN THE PRODUCTION OF POLYSTYRENE PLASTICS
}

\author{
Usmanova Regina Ravilyevna \\ Candidate of Technical Sciences, \\ Associate Professor, Department of Resistance of Materials, \\ Ufa State Aviation Technical University \\ usmanovarr@mail.ru \\ K. Marksa St., 12, 450025 Ufa, Russian Federation
}

\section{Zaikov Gennadiy Efremovich}

Doctor of Chemical Sciences, Professor, Head of Department of Biological and Chemical Physics of Polymers, Institute of Biochemical Physics named after N.M. Emanuel, RAS chembio@sky.chph.ras.ru Kosygina St., 4, 119334 Moscow, Russian Federation

\begin{abstract}
The assessment of the cost-effectiveness of measures to protect the environment was carried out. Relations are obtained to calculate the damage caused by atmospheric emissions in the production of polystyrene. Criteria for technical and economic evaluation of the effectiveness of gas purification system were developed. A method for estimating gas treatment facilities, allowing the design stage to make a comparative analysis of competing systems, taking into account the costs of implementation of environmental measures.

Key words: ecological efficiency, environmental damage, atmospheric emissions, rotoklon, efficiency criterion, the maximum permissible concentration.
\end{abstract}

\section{Current state of a problem}

吕

The continuously growing production capacity of plastics used in the technology of new materials, leads to continuous improvement of gas cleaning practices used in industrial processes. This improvement in the coming years will be in line with the trend of the gas cleaning in general. In the future preference will be given to the methods and apparatus providing fine cleaning of exhaust gas streams from harmful substances. The optimisation problem is closely connected with various alternatives of designs, characteristics for designing the gas-cleaning installations and constructions. The survey of the domestic and foreign literature $[5 ; 7 ; 13]$ has revealed a total absence of attempts to find the solution of this problem of in the stated aspect. Moreover, the attempts to optimise the constructive and technological parametres of any unique apparatus within the limits of its use in concrete conditions were not taken.

The preliminary study of the problem has shown its complexity. The way to its solution consists in the mathematical construction of technical and economic models of optimised installations, i.e. the equations in 
which the constructive and technological as well as technical and economic parametres would be connected together. Now such model exists only with the reference to cyclonic installations $[7 ; 15]$.

The special attention is given to the preparation and the analysis of technical projects on designing, as the experiment shows. The bases of design quality are put at these early stages of the work.

It is possible to note the momentous defects, the overcoming of which demands the future years.

1. Insufficiency of the nomenclature of a gas-cleaning installation and its lag from growing powers of the industry.

2. Weakness of computational baseline in which the empiric element predominates.

3. Absence of strict scientific criteria for designing a gas-cleaning installation of constructions with two and more clearing steps. For the specified reason at designing of such constructions the big role is played by purely heuristic factor.

4. The weakest and improbable working out of the questions connected with drawing by the flying emissions of a damage to a circumambient and, accordingly, with definition of economic benefit of liquidation of this damage.

These and other unresolved problems should be solved by the development engineers, initiating to master designing a gas-cleaning installation of constructions. Central tasks which were put by working out of a new build of a rotoklon with inner circulation of a liquid:

- to produce the criteria of the technical and economic estimation of system effectiveness in the sphere of environment protection against pollution;

- to create the apparatus with a wide range of operating conditions change and a wide scope, including for clearing gases of the basic industrial assemblies of finely divided dust.

\section{Calculation of the prevented damage from atmospheric air pollution}

The prevented ecological damage from pollutant emissions in an aerosphere - an estimation in the monetary form of possibly negative aftereffects from pollutant emissions which in an observed time span it was possible to avoid as a result of activity of supervising authorities in metrology, conducting a complex of provisions, implementation of nature protection programs. At implementation a gas-cleaning installation was momentous to define magnitude of an economic damage in the set region, prevented as a result of conducting nature protection provisions on air protection from pollutant emissions $[1 ; 10]$.

The integrated estimation of magnitude of the prevented damage from pollutant emissions can be spent to an aerosphere as for one large source or group of sources, and for region as a whole. In the capacity of sized up group of sources all sources in the given city, the region, observed as a uniform source can be observed.

Prevention of economic damage from the emission of pollutants into the air, where $\mathrm{y}_{p}$, thousand rubles is given by:

$$
\mathrm{y}_{p}=\mathrm{y}_{y} \cdot M_{p r} \cdot K_{e} \cdot I_{\text {д }}
$$

where $\mathrm{Y}_{p}$-a parameter of a specific damage from pollutant emissions in free air in the observed economic region of the Russian Federation, Russian rouble/ton; $K_{e}$ - factor of the ecological situation and the ecological significance in open-air conditions on the territories of Russian economic regions; $I_{д}$-an index on the industries, installed by Ministry of Economics of Russia. We accept equal 1; $M_{p r}$ - a pollutant emission reduced mass in the region, scaled down as a result of conducting of matching nature protection provisions, thousand tons/year.

$$
\begin{gathered}
M_{p r}=\Delta M-M_{c}, \\
\Delta M=M_{1}-M_{2}+M_{\text {new }}:
\end{gathered}
$$

where $\Delta M-$ total volume of a reduced mass of the scaled down waste interception, thousand conditional, tons/year; $M_{c}-$ a reduced mass of the waste interception which has been scaled down as a result of slump in production in region, thousand conditional, tons/year; $M_{1}$ and $M_{2}-$ accordingly a waste interception reduced mass on the beginning and the end of the desing period, thousand conditional, tons/year; $M_{\text {new }}-$ a reduced mass of waste interception of the new factories and manufactures, thousand conditional, tons/year.

For calculation of a reduced mass of pollution the confirmed values of maximum-permissible concentration (maximum concentration limit) of pollutants in water of ponds are used. By means of maximum concentration limit factors of ecological and economic hazard of pollutants as magnitude, return maximum concentration limit are defined. 

formula:

The reduced mass of pollutants pays off by

$$
M=\sum_{i=1}^{N} m_{i} \cdot K_{e i},
$$

where $m_{i}$ - mass of actual waste interception of pollutant in water installations of observed region, tons/year; $K_{e i}$ - factor of relative ecological and economic hazard to pollutant; $N$ - quantity of considered pollutants; $i$ - substance number in the Table.

\section{Technical and ecological assessment gas-cleaning plant sampling}

In ecology and harmonious exploitation bases estimations of economic efficiency of nature protection provisions are resulted. The problem is put to inject into calculation of a damage to a circumambient $Y$ operational parametres of the given clearing installation to pass to relative magnitudes. It will allow to scale down number of the factors which are not influencing functioning of system, to devise methods of calculation of relative efficiency a gas-cleaning installation of the constructions, giving the chance to choose the most rational approaches and the equipment of systems of trapping the harmful atmospheric emissions. In the most general case, the damage $A_{t}$, caused by atmospheric emissions can be computed as $\mathrm{y}=B \cdot M$. The reduced mass of emission incorporating $N$ of components, will be computed in an aspect:

$$
M=\sum_{i=1}^{N} A_{i} \cdot m_{i} .
$$

The emission mass $m_{i}$ is proportional to an overshoot through system

$$
m_{i}=\left(1-\eta_{i}\right) \cdot m_{o i} .
$$

In the industrial practice it is normally set or the share of concrete pollution in departing gas is known, $C_{o i}$. We will consider gas diluted enough so its density $c$ does not depend on the presence of admixtures

$$
m_{o i}=C_{o i} \cdot \rho \cdot Q .
$$

Let's compute a damage caused to an aerosphere, per unit masses of trapped pollution $\mathrm{Y}_{m}$

$$
\mathrm{y}_{m}=\frac{B \cdot \sum_{i=1}^{N} A_{i} \cdot\left(1-\eta_{i}\right) \cdot C_{o i}}{\sum_{i=1}^{N} \eta \cdot C_{o i}} .
$$

If to size up the gas-cleaning plant on average parametres, $\eta_{i}=\eta$

$$
\begin{aligned}
& A=\frac{1}{N} \cdot \sum_{i=1}^{N} A_{i} \cdot C_{o i}, \\
& \mathrm{y}_{m}=\frac{B \cdot A \cdot(1-\eta)}{\eta} .
\end{aligned}
$$

Let's formulate a principle of ecological efficiency of nature protection provisions at least a damage put to a circumambient. Purpose function in this case will appear in the form of $\mathrm{Y}_{m} \rightarrow \min$. Magnitude $\mathrm{y}_{m}$ diminishes with value growth

$$
E=\frac{\sum_{i=1}^{N} \eta_{i} \cdot C_{o i}}{B \cdot \sum_{i=1}^{N} A_{i} \cdot\left(1-\eta_{i}\right) \cdot C_{i}} .
$$

We will consider magnitude $E$ as a criterion of ecological efficiency of nature protection provisions. The criterion of relative ecological efficiency $\Theta$ is representable in the form of the relation of values $E$ computed for compared alternative $E_{1}$ and the base accepted in the capacity of $E_{0}$

$$
\Theta=E_{1} / E_{0} .
$$

In case of the single-component pollution of criterion of relative ecological efficiency we will find as

$$
\Theta=\frac{\eta_{1}}{\eta_{0}} \cdot \frac{1-\eta_{0}}{1-\eta_{1}} .
$$

Thus, for two gas-cleaning plants of the concrete manufacture, different in separation extent, $\eta_{1} \neq \eta$, relative ecological efficiency of system is sized up by technological parameter $\Theta \rightarrow$ max. The prevented damage $\mathrm{y}_{p}$ compute as a difference between economic losses of two competing alternatives as $\mathrm{y}_{p}=\mathrm{y}_{0}-\mathrm{y}_{1}$.

We will be restricted to an event of comparison of two alternatives of clearing gas emissions intended for the same manufacture with fixed level of technological perfection. In the capacity of base alternative $\mathrm{Y}_{0}$ we will accept the greatest possible damage atmospheric emissions of the manufacture which technological circuit design does not provide a clearing stage, $\eta_{i o}=0$. For the fixed technological circuit design of manufacture efficiency of a stage of clearing we will size up in shares from the maximum damage $E_{\mathrm{n}}=\mathrm{y}_{p} / \mathrm{y}_{o}$ 


\section{ТЕХНИКО-ТЕХНОЛОГИЧЕСКИЕ ИННОВАЦИИ}

$$
E_{\mathrm{\Pi}}=\frac{\mathrm{y}_{p}}{\mathrm{y}_{o}}=\frac{\sum_{i=1}^{N} A_{i} \cdot C_{i} \cdot \eta_{i}}{\sum_{i=1}^{N} A_{i} \cdot C_{i}} .
$$

If we consider that all components of harmful emission with aggression average indexes are trapped in equal extents $\left(A_{i}=A\right.$, $\eta_{i}=\eta$ ) we come to $E_{n}=\eta$. Thus, the eurysynusic extent of trapping $\eta$ is a special case of criterion of ecological efficiency $E_{\pi}$. computed for one-parametric pollution or for emission with average characteristics. At sampling of the gascleaning plant it is necessary to give preference to the installation securing higher values of criterion $E_{\Pi}$.

The gas-cleaning installation demands expenses $Z(\mathrm{rbl} / \mathrm{c})$ on the creation and functioning. These charges can essentially differ depending on the accepted method of clearing gas emissions and should be taken into consideration at the estimation of the general damage. For example, air purification from a dust cyclone separators will be more lowcost in the "dry" way "wet" at which it is necessary to provide additional charges on water, pumping devices, neutralisation of runoffs etc. At the same time centrifugal separators are not suitable for clearing gaseous impurities. We will use relative parameters, i.e. to consider a gain of the prevented damage $\Delta \mathrm{y}_{p}=\mathrm{y}_{1}-\mathrm{y}_{2}$ on rouble of expenses $\Delta Z$.

Function of the purpose $\mathrm{y}_{p} \rightarrow \max$ will register in an aspect

$$
E_{\Pi}=\left(\Delta \mathrm{y}_{\Pi} / \Delta Z\right) \rightarrow \max .
$$

We will be restricted to consideration of the method of calculating the magnitude $\mathrm{y}_{p}$ for centrifugal dust traps widely used in practice. We will define in maintenance costs a variable component of the power inputs connected with a water resistance of the apparatus $\Delta P$ (pascal). The Head loss $\Delta H=\Delta \mathrm{P} / \mathrm{\rho}(\mathrm{J} / \mathrm{kg})$ is definable from the Bernoulli's theorem which has been written down for entrance and target cross-sections of the gas passage. The energy consumption will be computed as $I=\Delta P \cdot Q(\mathrm{~J} / \mathrm{s})$.

Power inputs $Z_{\mathrm{e}}$ in terms of energy $\operatorname{costs} C_{e}$ (Russian rouble/J) is definable from a relationship

$$
Z_{e}=C_{e} \cdot Q \cdot \Delta P .
$$

The prevented damage $\mathrm{y}_{p}$ computed on rouble of expenses we will find as

$$
E_{\Pi}=\frac{B \cdot \rho \cdot \sum_{i=1}^{N} A_{i} \cdot C_{o i} \cdot \eta_{i}}{C_{e} \cdot \Delta P} .
$$

The criterion of relative ecological efficiency of the whirlwind apparatus $\Theta_{\Pi}=E_{\pi 1} / E_{\pi 0}$, is computed on values $E_{\Pi}$ for two installations $E_{\Pi 1}$ and $E_{\mathrm{n} 0}$, from which one is accepted for base $E_{\mathrm{\Pi} 0}$. At transition to average magnitudes

$$
\Theta_{\Pi}=\frac{\Delta P_{0} \cdot \eta_{1}}{\Delta P_{1} \cdot \eta_{0}} .
$$

Let's apply the results received earlier according to efficiency of clearing gas emissions to the comparative analysis of dust extractors of centrifugal action by criterion $\Theta$. As the base two-stage installation of type "cyclone C-6" is accepted. The results of the comparative analysis are introduced in Table 1. As the introduced data

Table 1

Comparative technical and economic indicators of offered and base dust-collecting plants

\begin{tabular}{|r|l|c|c|c|}
\hline \multicolumn{1}{|c|}{ № } & \multicolumn{1}{|c|}{ The indicator name } & $\begin{array}{c}\text { Unit } \\
\text { Measurements }\end{array}$ & $\begin{array}{c}\text { Basic } \\
\text { hardware }\end{array}$ & $\begin{array}{c}\text { New } \\
\text { installation }\end{array}$ \\
\hline 1 & Productivity & $\mathrm{m}^{3} / \mathrm{s}$ & 6 & 6 \\
\hline 2 & Hydraulic resistance & Pascal & 2100 & 1350 \\
\hline 3 & Factor of hydraulic resistance & - & 10,8 & 6,9 \\
\hline 4 & Concentration of emissions after installation & $\mathrm{Mg} / \mathrm{m}^{3}$ & 127,5 & 39 \\
\hline 5 & The occupied space in the plan & $\mathrm{m}^{2}$ & 17 & 5,3 \\
\hline 6 & Metal consumption & $\mathrm{m}^{2}$ & 6,8 & 4,9 \\
\hline 7 & The general power consumption & $\mathrm{kilowatt}^{2} \mathrm{~h}$ & 30 & 31 \\
\hline 8 & $\begin{array}{l}\text { The specific expense of the electric power on } \\
\text { clearing 1 000 }{ }^{3} \text { emissions }\end{array}$ & $\mathrm{kilowatt} \cdot \mathrm{h}$ & 0,6 & 0,475 \\
\hline 9 & Intensity of flow & $\mathrm{kg} / \mathrm{h}$ & - & 0,5 \\
\hline 10 & Criterion of efficiency $\eta$ & - & 1,0 & 1,85 \\
\hline
\end{tabular}


shows, the criterion of relational technical and ecological efficiency $\Theta$ reflects logic of process of dust separation - a device purification efficiency $\eta$, the magnitude $\Theta$ is more. In this case instead of qualitative ascertaining of the fact the quantitative assessment of efficiency of the clearing of gas emissions is offered, allowing to define in what degree competing systems differ from each other.

On Fig. 1 the results of research on separating ability of a rotoklon depending on conditional speed of gas $v$, calculated on full section of the device are introduced.

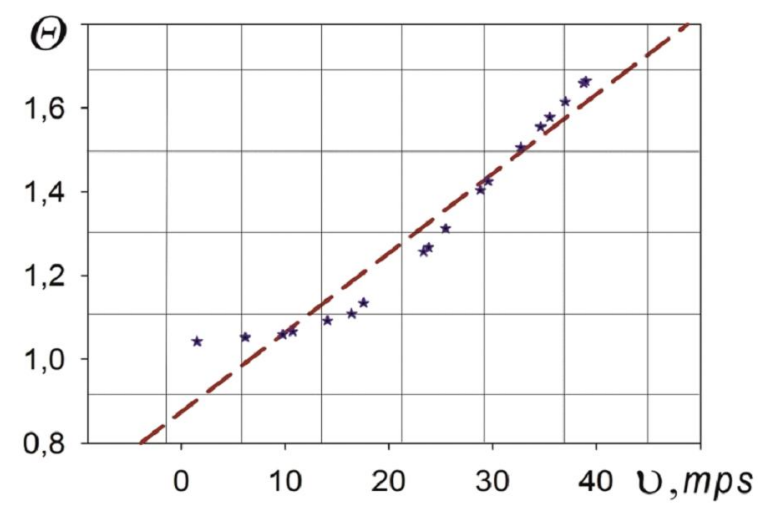

Fig. 1. Relative technical and economic efficiency of a rotoklon

Comparison of considered devices by means of criterion relative technical and economic efficiency $\Theta$ is conducted. The cited data has illustrative character and shows possibilities of application of criteria of technical and economic efficiency $\Theta$ for comparing the purposes of gascleaning plant devices.

\section{Results of industrial tests of the gas-cleaning plant on the basis of Rotoklon device}

Fig. 2 shows a schematic diagram of the cleaning process. In this scheme, a combined gas stream from one of the fan apparatus 2 is supplied to the furnace-heater 3 wherein the heat of combustion of the natural gas heated to temperature (from 350 to $400{ }^{\circ} \mathrm{C}$ ). Heated gases at a flow rate of up to $200 \mathrm{~s}^{-1}$ to enter rotoklon 5 . The outgoing gases from the apparatus, heated to 350 to $400{ }^{\circ} \mathrm{C}$, vented to the atmosphere through the heat exchanger 7 .

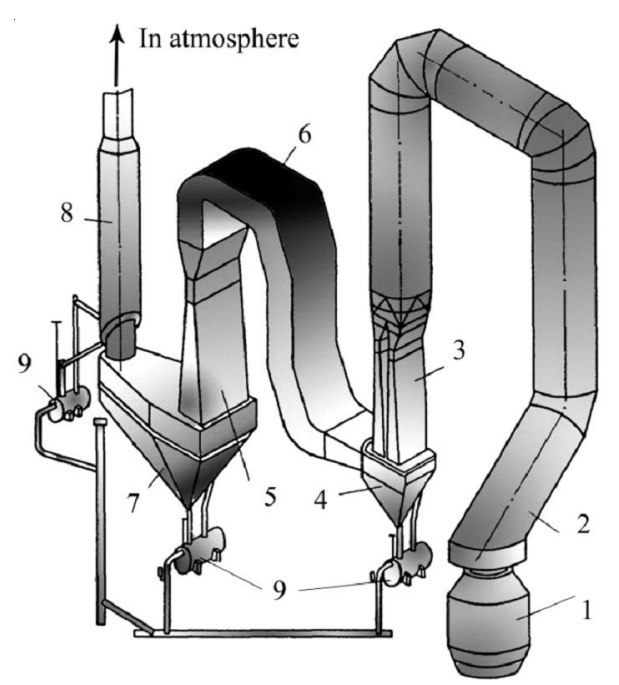

Fig. 2. The technological scheme of purification of gas emissions plastics production:

1- mixer flows; 2 - gas exit branch; 3 - Venturi scrubber; 4 - bunker - drop catcher; 5 - a rotoklon;

6 - gas pipeline; 7 - heat exchanger; 8 - exhaust pipe; 9 tank - a hydraulic hitch

The slope breeching 2, actually is the hollow scrubber in diameter of $400 \mathrm{~mm}$ working in the evaporation cooling regime. At work gases arrive from it in a Venturi scrubber 3, consisting of two cylindrical columns in diameter of $1000 \mathrm{~mm}$ with the general bunker. In each column of a scrubber it is established on three atomizers. The Venturi scrubber of the first step of clearing has a mouth in diameter of $100 \mathrm{~mm}$ and is irrigated with water from an atomizer established in front of the confusor.

Gases after a slope breeching go at first to the bunker the drop catcher 4 , and then in a rotoklon of the another step which consists from the heat exchanger 7 . The exhaust of gases from the furnace is carried out by vacuum pump VVN50 established behind devices of clearing gas emissions. Purified gases are deduced in atmosphere.

The regulation of gases pressure under a furnace roof and the expense of gases is carried out by a throttle in front of the vacuum pump. Slurry water from devices of clearing gas emissions flows off a by gravity in a tank of a hydroshutter 9 , whence also a by gravity arrives in a slurry tank. From a slurry tank water on two slurry clarifier is taken away on water purification. After clarification, chemical processing and cooling water is fed again by the pump on irrigating the gas-cleaning installations. 


\section{ТЕХНИКО-ТЕХНОЛОГИЧЕСКИЕ ИННОВАЦИИ}

The dust contained in gases differs in high dispersion (to 80 weight $\%$ of particles less than $5 \div 6$ microns). In Table 2 the compound of a dust of exhaust gases is resulted.

Table 2

Results of posttest examination

\begin{tabular}{|l|c|c|}
\hline Compound & $\begin{array}{c}\text { Requisite } \\
\text { concentration, } \mathrm{g} / \mathrm{m}^{3}\end{array}$ & $\begin{array}{c}\text { Concentration after } \\
\text { clearing, } \mathrm{g} / \mathrm{m}^{3}\end{array}$ \\
\hline Dust & 0,02 & 0,00355 \\
\hline $\mathrm{NO}_{2}$ & 0,10 & 0,024 \\
\hline $\mathrm{SO}_{2}$ & 0,03 & 0,0005 \\
\hline $\mathrm{CO}$ & 0,01 & 0,0019 \\
\hline
\end{tabular}

In tests for furnaces almost constant electric regime that secured with identity of conditions at which parametres of systems of dust separation characterize was supported. The furnace worked on the fifth - the seventh steps of pressure at fluctuations of capacity $14.5 \div 17.5$ megawatt.

The quantity of dry gases departing from the furnace made $1500 \div 2000 \mathrm{~m}^{3} / \mathrm{h}$. The temperature of gases before clearing of gas emissions equaled $750 \div 850{ }^{\circ} \mathrm{C}$ and humidity did not exceed $4 \div 5 \%$ (on volume).

In Table 3 results of calculation of a payment for pollutant emission of system of dust separation are shown.

Thus, we have chosen the scheme of gases clearing which allows to lower concentration of pollutants to preset values and consequently, and to lower payments by the enterprise for emissions.

\section{Conclusions}

1. On the basis of economic efficiency evaluation method for carrying out nature protection measures, relations for calculation of the damage put to environment by gas emissions are revealed. Transition to relative indicators has allowed to scale down number of the factors which are not influencing process of clearing of gas emissions.

2. Methods of an estimation a gas-cleaning installation of the constructions are devised, allowing on a design stage to make the comparative analysis of competing systems in terms of expenses for realisation of nature protection actions.

3. Criteria of estimating the technical and ecological gas-cleaning plants, incorporating both economic, and technology factors are developed.

\section{REFERENCES}

1. A Time Typical Technique of Definition of Economic Efficiency of Realisation of Nature Protection Actions and an Estimation of the Damage Caused to a National Economy by Environmental Pollution. Leningrad, Gidro-Meteo Publ., 1986. 125 p. (in Russian).

2. Bakhracheva Yu.S. Otsenka vyazkosti razrusheniya staley po rezultatam kontaktnogo deformirovaniya [Evaluation of Viscosity of Steel Destruction According to the Results of Contact Deformation]. Vestnik Volgogradskogo gosudarstvennogo universiteta. Seriya 10, Innovatsionnaya deyatelnost [Science Journal of Volgograd State University. Technology and Innovations], 2012, no. 7, pp. 53-56. (in Russian).

3. Baron A.A., Bakhracheva Yu.S., Osipenko A.P. Fracture Toughness Estimation by Means of Indentation Test. Mekhanika, 2007, vol. 67, no. 5, pp. 33-36.

4. Baron A.A., Gevlich D. S., Bakhracheva Yu.S. Specific Plastic Strain Energy as a Measure of the

Table 3

Results of calculation of payment for pollutant emission

\begin{tabular}{|c|c|c|c|c|c|c|c|}
\hline \multirow[t]{3}{*}{$\begin{array}{l}\text { The list of pollutants } \\
\text { (the substance name) }\end{array}$} & \multicolumn{3}{|c|}{$\begin{array}{c}\text { It is thrown out } \\
\text { for the accounting period, } \\
\text { t/year }\end{array}$} & \multirow{3}{*}{$\begin{array}{c}\text { The base } \\
\text { specification } \\
\text { of a payment } \\
\text { within } \\
\text { admissible } \\
\text { specification } \\
\text { s, a Russian } \\
\text { rouble/t }\end{array}$} & \multirow{3}{*}{$\begin{array}{l}\text { The size of a } \\
\text { payment for } \\
\text { a maximum } \\
\text { permissible } \\
\text { emission, } \\
\text { Russian } \\
\text { rouble/ } \\
\text { year }\end{array}$} & \multirow{3}{*}{$\begin{array}{l}\text { The base } \\
\text { specification } \\
\text { of a payment } \\
\text { within the } \\
\text { established } \\
\text { limits, a } \\
\text { Russian } \\
\text { rouble/t }\end{array}$} & \multirow{3}{*}{$\begin{array}{c}\text { Total } \\
\text { payment } \\
\text { on the } \\
\text { enterprise, } \\
\text { a Russian } \\
\text { rouble/year }\end{array}$} \\
\hline & \multirow[b]{2}{*}{ In total } & \multicolumn{2}{|c|}{ Including } & & & & \\
\hline & & VPE & MPE & & & & \\
\hline The inorganic Dust: & 19710 & - & - & 21 & 228,65 & 105 & 228,65 \\
\hline Nitrogen dioxide & 105,1 & - & - & 52 & 379,19 & 260 & 379,19 \\
\hline Carbon monoxide & 288,2 & - & - & 0,6 & 2,99 & 3 & 2,99 \\
\hline Sulfurs dioxide & 197,1 & - & - & 40 & 539,14 & 200 & 539,14 \\
\hline Total & - & - & - & - & 1149,97 & - & 1149,97 \\
\hline
\end{tabular}




\section{ТЕХНИКО-ТЕХНОЛОГИЧЕСКИЕ ИННОВАЦИИ}

Cracking Resistance of Structural Materials. Russian Metallurgy (Metally), 2002, no. 6, pp. 587-592.

5. Belevitskiy A.M. Economy and Technical and Economic Optimisation of Dust-Collecting Plants (on the Example of Installations of Cyclonic Dust Separation): Help Supervising Material. Clearing of Gas Emissions. Industrial and Sanitary Gas Cleaning, 1982, no. 6, pp. 17-32.

6. Belova S.V., ed. Environmental Control. Moscow, Vysshaya shkola Publ., 1991. 286 p. (in Russian).

7. Brodskiy Y.N., Melnikova L.N. Sanitary Cleaning of Styrenated Gases. Industrial and Sanitary Gas Cleaning, 1985, no. 5, pp. 23-31.

8. Denisenko L.I., et al. Quality Monitoring and Clearing of Plant Emissions of Various Manufactures of Fluoric Connections. Moscow, Tsintikhim-neftemash Publ., 1982. 334 p. (in Russian).

9. Eldyshev Y.N. World Against Plastic Bags. Ecology and Life, 2011, no. 7, pp. 32-39.

10. Gorfinkelja V.J., Shvandara V.A., eds. Enterprise Economy. Moscow, JUNITI-DANA, 2007. 458 p. (in Russian).

11. Grigoryev E., Vasilyev A., Dolgov K. The Influence of the Arrangement Scheme on Balancing and Mass Dimension Parameters of Engines. Mekhanika, 2006, vol. 61, no. 5, pp. 46-50.

12. Ivanov I.P, Kogan B.I., Bulls A.P. Engineering Ecology. Novosibirsk, Izd-vo NSGTU, 1995. 321 p. (in Russian).

13. Kouzov I.A., Malgin A.D., Skryabin M. Dust Element of Gases and Air in a Chemical Industry. Leningrad, Khimiya Publ., 1982. 256 p. (in Russian).

14. Maksimova V.F., ed. Clearing and $a$ Regeneration of Plant Emissions. Moscow, Lesnaya promyshlennost Publ., 1981. 216 p.

15. Nikanorov A.A. Sources and Methods of Clearing of Gas Bursts of Ozone. Moscow, 1985. 334 p. (in Russian).

16. Radionov A.I., Klushin V.N., Gorshechnikov N.S. Techniques of Environment
Protection. Moscow, Metallurgiya Publ., 1989. 148 p. (in Russian).

17. Rodions A.I., Klushin C.H., Sister C. Technological Processes of Environmental Safety. Kaluga, Izd-vo N. Bochkarevoy, 2000. 336 p. (in Russian).

18. Semenova L.M., Bakhracheva Yu.S., Semenov S.V. Laws of Formation of Diffusion Layers and Solution of the Diffusion Problem in TemperatureCycle Carbonitriding of Steel. Metal Science and Heat Treatment, 2013, vol. 55, no. 1-2, pp. 34-37.

19. Shapochkin V.I., Semenova L.M., Bakhracheva Yu.S., Gyulikhandanov E.L., Semenov S.V. Effect of Nitrogen Content on the Structure and Properties of Nitrocarburized Steel. Metal Science and Heat Treatment, 2011. vol. 52, no. 9-10, pp. 413-419.

20. Skryabin J.I. The Industrial Dust Atlas. Moscow, Tsintikhim-neftemash Publ., 1982. 76 p. (in Russian).

21. Straus V. Industrial Clearing of Gases. The Lane with English. Moscow, Khimiya Publ., 1981. 197 p. (in Russian).

22. The Equipment for Gas Emissions Clearing. The Catalogue. Environmental Control. Moscow, Khimiya Publ., 1992. 245 p. (in Russian).

23. Timina V.M., ed. Enterprise Economy. Saint Petersburg, Khimiya Publ., 2006. 378 p. (in Russian).

24. Vasilyev A., Deynichenko E., Popov D. Internal Combustion Engine Valve Gear Cam Wear and Its Influence on Valve Gear and Engine Efficiency. Mekhanika, 2005, vol. 54, no. 4, pp. 44-49.

25. Vasilyev A. Simulation of Valve Gear Dynamics Using Generalized Dynamic Model. Mekhanika, 2006, vol. 58, no. 2, pp. 37-43.

26. Vasilyev A., Dolgov K. The Arrangement Scheme and Its Influence on Vibration Process of the Vehicle Piston Engine. Mekhanika, 2007, vol. 66, no. 4, pp. 44-48.

27. Weinstein M., Krasnik I.M., Durable C.D. Industrial and Sanitary Clearing of Gases. Industrial and Sanitary Gas Cleaning, 1977, no. 5, pp. 3-14.

\section{ОБЕЗВРЕЖИВАНИЕ ГАЗОВЫХ ВЫБРОСОВ ПРИ ПРОИЗВОДСТВЕ ПОЛИСТИРОЛЬНЫХ ПЛАСТИКОВ}

\section{Усманова Регина Равильевна}

Кандидат технических наук, доцент кафедры сопротивления материалов, Уфимский государственный авиационный технический университет usmanovarr@mail.ru ул. К. Маркса, 12, 450025 г. Уфа, Российская Федерация 


\section{Заиков Геннадий Ефремович}

Доктор химических наук, профессор,

заведующий отделом биологической и химической физики полимеров,

Институт биохимической физики им. Н.М. Эмануэля РАН

chembio@sky.chph.ras.ru

ул. Косыгина, 4, 119334 г. Москва, Российская Федерация

Аннотация. В ходе работы была проведена оценка экономической эффективности мер по охране окружающей среды. Был рассчитан ущерб, причиненный в результате атмосферных выбросов при производстве полистирола. Разработаны критерии технико-экономической оценки эффективности системы газоочистки.

Ключевые слова: экологическая эффективность, экологический ущерб, выбросы в атмосферу, «ротоклон», критерий эффективности, предельно допустимая концентрация. 